\title{
IDENTIFIKASI INFERTILITAS PADA PRIA DENGAN MENGGUNAKAN METODE CASE BASED REASONING
}

\author{
Mellya Rindhani Aditia ${ }^{1)}$ \\ 1) Universitas Putra Indonesia YPTK, Padang \\ email: mellyaditia@yahoo.com
}

\begin{abstract}
Abstrak
Sistem pakar merupakan sebuah sistem yang dibangun dengan prinsip cerdas sebab salah satu cabang dari ilmu kecerdasan buatan. Yang menjadikannya cerdas dikarenakan memiliki pengetahuan yang ditanamkan kedalamnya yang bersumber dari satu atau lebih pakar yang memiliki pengetahuan dibidangnya. Metode case based reasoning digunakan sebagai mesin inferensi dalam penelitian ini dikarenakan metode ini akan mencari kemiripan dengan kasus lama dengan kasus baru yang dikonsultasikan oleh user. Penyakit infertilitas merupakan gangguan terhadap sistem reproduksi yang dapat mengakibatkan kegagalan dalam mencapai kehamilan klinis setelah 12 bulan atau lebih dalam berhubungan intim dengan teratur tanpa alat kontrasepsi. Sistem Pakar yang dibangun digunakan dalam identifikasi Infertilitas pada pria menggunakan metode case based reasoning bertujuan menelusuri gejala yang disediakan kedalam bentuk pertanyaan konsultasi supaya user dapat mendiagnosa penyakit dengan perangkat lunak berbasis web. Perangkat lunak sistem pakar dapat mengenali gejala penyakit infertilitas yang dialami oleh user setelah menjawab pertanyaan konsultasi yang ditampilkan serta menyimpulkan beberapa tingkat persentase infertilitas yang dialami oleh user.
\end{abstract}

Kata Kunci: Sistem Pakar, Case Based Reasoning, Infertilitas

\begin{abstract}
Expert sistem is a sistem that was built with intelligent principles because it is a branch of the science of artificial intelligence. What makes it smart is because it has knowledge that is implanted into it which is sourced from one or more experts who have knowledge in their fields. Case-based reasoning method is used as an inference engine in this study because this method will lookfor similarities with old cases with new cases consulted by the user. Infertility is a disorder of the reproductive sistem that can lead to failure to achieve clinical pregnancy after 12 months or more in having sex with regular without contraception. Expert sistem that was built is used in identifying infertility in men using the case-based reasoning method aimed at tracing the symptoms provided in the form of consultation questions so that users can diagnose the disease with web-based software. Expert sistem software can recognize the symptoms of infertility experienced by the user after answering the consultation questions that are displayed and conclude some level of percentage of infertility experienced by the user.
\end{abstract}

Keywords: Expert Sistem, Case Based Reasoning, Infertility

\section{PENDAHULUAN}

Dalam jurnal penelitian yang dilakukan oleh [1] yang mengutip dari jurnal berberjudul aplikasi sistem pakar dalam mendiagnosa penyakit infertilitas pada pria menggunakan metode certainty factor berbasis web menyimpulkan bahwa mendiagnosa penyebab infertilitas pada pria, karena di dalam sistem pakar ini diberikan pengetahuan berupa gejala-gejala yang digunakan sebagai masukan terhadap konsultasi user. 
Permasalahan pada pria berupa infertilitas perlu penanganan dan diperhatikan secara serius, presentase yang besarnya pada pria cukup besar yaitu menfcapai $( \pm 40-60 \%)$ berupa gangguan pada kesuburan. Selain itu penanganan infertilitas pada pria merupakan salah masalah yang sangat kompleks dan juga rumit. Dilihat dari dampak infertilitas tersebut, penulis menjadi tertarik dalam penelitian mengenai sistem pakar yang dapat dimanfaatkan untuk melakukan identifikasi infertilitas terhadap pria, sistem yang dibangun berbasiskan web dengan harapan supaya dapat menjadi mudah bagi pengguna untuk melakukan akses dan sistem ini juga mampu memberikan pengetahuan yang secara optimal dari timbal balik antara pengguna dengan sistem.

Dalam proses Analisa terhadap identifikasi penyakit infertilitas digunakan metode Case Based Reasoning, dimana metode ini merupakan penalaran berbasis kasus yang bertujuan untuk menyelesaikan suatu permasalahan baru dengan cara mengadaptasi solusi-solusi yang terdapat kasus-kasus sebelumnya yang mirip dengan kasus baru. Kasus baru dicocokkan (matched) dengan kasus-kasus yang ada di dalam basis data penyimpanan kasus (case base) dan menemukan satu atau lebih kasus yang mirip.

Penelitian sebelumnya mengenai metode Case Based Reasoning oleh [2] dengan hasil Sistem penalaran berbasis kasus untuk diagnosa kerusakan harddisk memiliki fasilitas untuk akuisisi basis data kasus dengan memberikan bobot pada gejala. Berdasarkan contoh kasus yang dilakukan dapat disimpulkan bahwa gejala A (Harddisk bad sector) memiliki kedekatan terhadap kasus lama sebesar 0,35 .
Dari hasil penelitian tersebut dapat disimpulkan bahwa metode sistem pakar dengan menggunakan case based reasoning dapat diterapkan untuk mendiagnosa suatu penyakit.

Gejala pada penyakit infertilitas banyak masyarakat yang kurang memiliki pengetahuan tentang gejala tersebut, sehingga masyarakat hanya memperoleh pengetahuan mengenai gejala penyakit dengan konsultasi pada dokter yang membutuhkan waktu dan biaya.

Dengan permasalahan tersebut diharapkan dapat diatasi dengan adanya sistem pakar yang dibangun untuk mengidentifikasi gejala infertilitas pada pria.

\section{LANDASAN TEORI}

\section{Kecerdasan Buatan}

Artificial Intelligence (AI) atau yang dapat kita diartikan sebagai kecerdasan buatan dan dapat kita jelaskan sebagai membuat komputer dapat melakukan sesuatu layaknya yang dapat dilakukan oleh manusia dimana sistem cerdas tersebut mempelajari ilmu pengetahuan dan teknologi yang mempelajari hal tersebut. Kecerdasan buatan juga dapat dijelaskan sebagai sebuah studi tentang hal yang mampu membuat komputer melakukan yang pada saat ini dapat dikerjakan oleh manusia [3].

Selama bertahun-tahun pada filsuf berusaha mempelajari kecerdasan yang dimiliki manusia. Dari pemikiran tersebut lahirlah AI sebagai cabang ilmu yang berusaha mempelajari dan meniru kecerdasan manusia. Sejak saat itu para peneliti mulai memikirkan perkembangan AI sehingga teori-teori dan prinsipnya berkembang terus hingga sekarang [4]. 
Kecerdasan Buatan saat ini sering dimanfaatkan dalam aplikasi medis untuk solusi dari pelengkap menemukan alternatif dalam permasalahan medis. Munculnya teknologi sistem cerdas dalam bidang kesehatan menjadi pacuan dalam pengembangan aplikasi sistem pakar dalam memberikan layanan kesehatan, salah satunya yaitu proses diagnosa suatu penyakit [5].

\section{Sistem Pakar}

Sistem pakar atau sistem berbasis pengetahuan atau sistem pengetahuan adalah sistem komputer yang dicirikan oleh fakta bahwa perbedaan eksplisit dibuat antara bagian di mana pengetahuan tentang domain masalah direpresentasikan dan bagian yang memanipulasi pengetahuan tersebut untuk memecahkan masalah aktual dengan menggunakan problem data [6].

Sistem pakar dapat disebut juga sebagai salah satu cabang dari AI yang membuat penggunaan secara luas knowledge yang khusus untuk penyelesaian masalah tingkat manusia yang pakar [8]. Seorang pakar adalah orang yang mempunyai keahlian dalam bidang tertentu, yaitu pakar yang mempunyai knowledge atau kemampuan khusus yang orang lain tidak mengetahui atau mampu dalam bidang yang dimilikinya. Pada saat pertama kali sekitar tahun 70-an, sistem pakar hanya berisi knowledge yang eksklusif. Namun demikian sekarang ini istilah sistem pakar sudah digunakan untuk berbagai macam sistem yang menggunakan teknologi sistem pakar itu [6].

\section{Case Based Reasoning}

Case-Based Reasoning (CBR) adalah metode untuk menyelesaikan masalah dengan mengingat kejadiankejadian yang sama/ sejenis (similar) yang pernah terjadi di masa lalu kemudian menggunakan pengetahuan/ informasi tersebut untuk menyelesaikan masalah yang baru, atau dengan kata lain menyelesaikan masalah dengan mengadaptasi solusi-solusi yang pernah digunakan di masa lalu [7].

\section{METODE PENELITIAN}

Kerangka penelitian adalah urutan yang akan dilakukan dalam suatu penelitian. Agar langkah-langkah yang diambil penulis dalam perancangan ini tidak melenceng dari pokok pembicaraan dan lebih mudah dipahami, maka urutan langkah-langkah penelitian akan dibuat secara sistematis dan dapat digunakan sebagai pedoman yang jelas serta mudah untuk menyelesaikan permasalahan yang ada. Urutan langkah-langkah yang akan dibuat pada penelitian ini dapat dilihat pada gambar berikut ini :

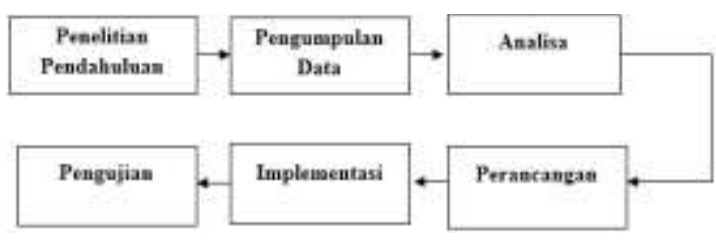

\section{Gambar 1. Metodologi Penelitian}

\section{HASIL DAN PEMBAHASAN}

\section{Analisa Data}

Proses analisa data yaitu merupakan salah satu tahapan yang penting dalam penelitian ini, karena pada tahap inilah nantinya dilakukan identifikasi terhadap penyakit Infertilitas pada pria, serta melakukan penganalisaan terhadap data yang diperoleh, dimana data dijadikan bahan untuk pembuatan aplikasi ini, data yang diperoleh adalah data mengenai gejala-gejala yang memungkinkan seorang 
pria terkena penyakit Infertilitas. Berikut adalah data mengenai penyakit Infertilitas:

\section{Tabel 1. Tabel Penyakit}

\begin{tabular}{|c|c|c|}
\hline No & Kode & Nama \\
\hline 1 & P01 & Infertilitas pada pria \\
\hline
\end{tabular}

Tabel 2. Tabel Gejala Infertilitas

\begin{tabular}{|c|c|c|c|}
\hline NO & Kode & Gejala & Bobot \\
\hline 1 & G001 & $\begin{array}{l}\text { Keluar darah pada } \\
\text { penis }\end{array}$ & 3 \\
\hline 2 & G002 & \begin{tabular}{ll}
\multicolumn{2}{l}{ Pembengkakan } \\
selangkangan pada \\
sisi testis yang \\
terkena
\end{tabular} & 1 \\
\hline 3 & G003 & $\begin{array}{l}\text { Pembengkakan pada } \\
\text { skroktum }\end{array}$ & 3 \\
\hline 4 & G004 & $\begin{array}{l}\text { Nyeri pada } \\
\text { selangkangan }\end{array}$ & 5 \\
\hline 5 & G005 & $\begin{array}{l}\text { Nyeri ketika } \\
\text { melakukan } \\
\text { hubungan seksual }\end{array}$ & 3 \\
\hline 6 & G006 & $\begin{array}{l}\text { Semen mengandung } \\
\text { darah }\end{array}$ & 1 \\
\hline 7 & G07 & $\begin{array}{l}\text { Nyeri ketika } \\
\text { berkemih }\end{array}$ & 5 \\
\hline 8 & G008 & $\begin{array}{l}\text { Testis terasa berat, } \\
\text { membengkak, lunak }\end{array}$ & 3 \\
\hline 9 & G009 & $\begin{array}{l}\text { Nyeri pada testis } \\
\text { yang bisa terjadi } \\
\text { ketika buang air } \\
\text { besar atau mengejan }\end{array}$ & 5 \\
\hline 10 & G010 & $\begin{array}{l}\text { Gatal-gatal pada } \\
\text { penis }\end{array}$ & 3 \\
\hline 11 & G011 & $\begin{array}{l}\text { Nyeri ketika buang } \\
\text { air besar, } \\
\text { pendarahan }\end{array}$ & 1 \\
\hline 12 & G012 & $\begin{array}{l}\text { Perasaan cemas, } \\
\text { sensitif, depresi, } \\
\text { mengantuk, letih dan } \\
\text { panik }\end{array}$ & 3 \\
\hline
\end{tabular}

\subsubsection{Analisa Proses}

Adapun analisa terhadap sistem pakar yang dibangun merupakan rule yang menerapkan metode $C B R$, metode $C B R$ merupakan satu metode yang digunakan untuk menghitung faktor kepastian dalam mengatasi kesulitan dari gejala-gejala infertilitas. Adapun logika metode $C B R$ pada sesi konsultasi sistem, pengguna konsultasi diberi pilihan jawaban yang masing-masing memiliki bobot.

\section{Analisa Proses}

Sebagai contoh, berikut merupakan data gejala yang diinputkan oleh pengguna aplikasi sistem pakar.

$$
\begin{aligned}
& \text { SP : Apakah terjadi keluar darah pada penis? } \\
& \mathrm{U} \text { : YA } \\
& \text { SP : Pembengkakan selangkangan pada sisi } \\
& \text { testis yang terkena? } \\
& \mathrm{U} \text { : YA } \\
& \text { SP : Apakah terjadi pembengkakan pada } \\
& \text { skroktum.? } \\
& \mathrm{U} \text { : TIDAK } \\
& \text { SP : Nyeri pada selangkangan? } \\
& \mathrm{U} \text { : TIDAK } \\
& \text { SP : Nyeri ketika melakukan hubungan } \\
& \text { seksual? } \\
& \mathrm{U} \text { : YA } \\
& \text { SP : Apakah Semen mengandung darah? } \\
& \mathrm{U} \text { : YA } \\
& \text { SP : Nyeri ketika berkemih? } \\
& \mathrm{U} \text { : YA } \\
& \text { SP : Apakah Testis terasa berat, } \\
& \mathrm{U} \text { : TIDAK } \\
& \text { SP : Apakah Nyeri pada testis yang bisa }
\end{aligned}
$$




\section{SP : Apakah Perasaan cemas, sensitif, depresi, mengantuk, letih dan panik? \\ $\mathrm{U}$ : TIDAK}

Dari hasil konsultasi diatas akan dilakukan proses pencarian dengan menggunakan metode Case Based Reasoning $(C B R)$, dimana prosesnya adalah sebagai berikut:

\section{Proses Retrieve}

Proses retieve merupakan proses pencarian kemiripan kasus baru dengan kasus lama yang ada pada basis pengetahuan. Pencarian kemiripan ini dilakukan dengan mencocokkan gejala yang di inputkan oleh pengguna dengan gejala yang ada pada basis pengetahuan. Pada awal proses diagnosa pengguna akan menginputkan gejala-gejala yang di alaminya secara sekaligus, selanjutnya pengguna akan mendapatkan hasil diagnosa. Sistem ini akan melakukan pembobotan dengan melakukan pencocokan satu persatu gejela-gejala yang ada di dalam basis pengetahuan. Adapun tahap pemrosesan kemiripan bobot yang dilakukan sistem akan dihitung dengan rumus berikut :

Similiarity $($ problem, case $)=$

$$
\frac{s 1 * w 1+s 2 * w 2+. . s n * w n}{w 1+w 2+. . w n}
$$

Keterangan :

a. $\mathrm{S}=$ Similiarity (nilai kemiripan), pada similiarity jika terdapat kemiripan kasus maka akan bernilai 1, sedangkan tidak mirip, maka bernilai 0

b. $\mathrm{W}=$ weight (bobot yang diberikan)

\section{Reuse}

Yaitu menggunakan kembali masalah atau kasus untuk mencoba memecahkan masalah atau kasus tersebut dan sistem akan melakukan penyesuaian terhadap kondisi kasus lama atau kasus pada tahap Retrive dengan kondisi saat ini.Sebagai contoh maka akan diambil pada kasus Baru Dengan Kode KB_001 yang memiliki gejala sebagai berikut :

Terjadi keluar darah pada penis, bobot $=$ 3

Pembengkakan selangkangan pada sisi testis yang terkena, bobot $=1$

Nyeri ketika melakukan hubungan seksual , bobot $=3$

Semen mengandung darah, bobot $=1$

Nyeri pada testis yang bisa terjadi ketika buang air besar atau mengejan, bobot $=5$

Nyeri ketika buang air besar, pendarahan, bobot $=1$

Dari kasus KB_001 maka akan dilakukan perbandingan dengan penyakit infertilitas yang lama, yaitu sebagai berikut:

\section{Tabel 3. Pencocokan Dengan Kasus P01}

\begin{tabular}{|l|c|}
\hline \multicolumn{1}{|c|}{ Gejala } & Bobot \\
\hline Keluar darah pada penis & 3 \\
\hline $\begin{array}{l}\text { Pembengkakan selangkangan pada sisi } \\
\text { testis yang terkena }\end{array}$ & 1 \\
\hline $\begin{array}{l}\text { Nyeri ketika melakukan hubungan } \\
\text { seksual }\end{array}$ & 3 \\
\hline Nyeri pada selangkangan & 5 \\
\hline Semen mengandung darah & 1 \\
\hline Nyeri ketika berkemih & 5 \\
\hline $\begin{array}{l}\text { Nyeri pada testis yang bisa terjadi } \\
\text { ketika buang air besar atau mengejan }\end{array}$ & 5 \\
\hline $\begin{array}{l}\text { Nyeri ketika buang air besar, } \\
\text { pendarahan }\end{array}$ & 1 \\
\hline
\end{tabular}

Tabel 4. Tabel Pencocokan Kasus Lama Dengan Kasus Baru

\begin{tabular}{|l|c|}
\hline Gejala & Bobot \\
\hline Keluar darah pada penis & 1 \\
\hline $\begin{array}{l}\text { Pembengkakan selangkangan pada } \\
\text { sisi testis yang terkena }\end{array}$ & 1 \\
\hline Pembengkakan pada skroktum & 0 \\
\hline Nyeri pada selangkangan & 1 \\
\hline
\end{tabular}




\begin{tabular}{|l|l|}
\hline $\begin{array}{l}\text { Nyeri ketika melakukan hubungan } \\
\text { seksual }\end{array}$ & 1 \\
\hline Semen mengandung darah & 1 \\
\hline Nyeri ketika berkemih & 1 \\
\hline $\begin{array}{l}\text { Testis terasa berat, membengkak, } \\
\text { lunak }\end{array}$ & 0 \\
\hline $\begin{array}{l}\text { Nyeri pada testis yang bisa terjadi } \\
\text { ketika buang air besar atau mengejan }\end{array}$ & 1 \\
\hline Gatal-gatal pada penis air besar, & 1 \\
\hline $\begin{array}{l}\text { Nyeri ketika buang depresi, } \\
\text { pendarahan }\end{array}$ & 0 \\
\hline $\begin{array}{l}\text { Perasaan cemas, sensitif, depantuk, letih dan panik } \\
\text { mengantuk, }\end{array}$ \\
\hline
\end{tabular}

Ket : Jika Gejala Sama bernilai 1, jika berbeda maka 0

Dari persaman gejala tersebut maka akan dicari tingkat kemiripan nya, yaitu dengan rumus :

$$
=\frac{\begin{array}{c}
\text { Similarity }(\text { problem, case }) \\
(s 1 * w 1) \ldots \ldots \ldots \ldots \ldots \ldots+(s 12 * w 12)
\end{array}}{w 1+\cdots \ldots \ldots+w 13}
$$

Dimana $\mathrm{s} 1=$ Bobot Kemiripan, $\mathrm{w} 1=$ bobot Gejala

$$
\begin{aligned}
& S(\text { problem, case }) \\
& \quad(1 * 3)+(1 * 1)+(0 * 3)+(1 * 5)+(1 * 3)+(1 * 1) \\
& =\frac{+(1 * 5)+(0 * 3)+(1 * 5)+(0 * 3)+(1 * 1)+(0 * 3)}{3+1+3+5+3+1+5+3+5+3+1+3} \\
& \quad S(\text { problem, case })=\frac{24}{36}=0,67
\end{aligned}
$$

Dari hasil diagonasa akan diambil bobot kesimpulan seperti tabel 5 .

Tabel 5. Persentase Kesimpulan Diagnosa

\begin{tabular}{|c|c|l|}
\hline NO & $\begin{array}{c}\text { Tingkat } \\
\text { Persentase }\end{array}$ & \multicolumn{1}{|c|}{ Nilai Keyakinan } \\
\hline 1 & $0-50 \%$ & $\begin{array}{l}\text { Sedikit kemungkinan } \\
\text { atau kemungkinan kecil }\end{array}$ \\
\hline 2 & $51-79 \%$ & Kemungkinan \\
\hline 3 & $80-99 \%$ & Kemungkinan Besar \\
\hline 4 & $100 \%$ & Sangat Yakin \\
\hline
\end{tabular}

Dari bobot kemiripan pada tabel 5. Maka disimpulkan bahwa pasien tersebut Kemungkinan terkena penyakit infertilitas.

\section{SIMPULAN}

Dari uraian masalah di atas, serta berdasarkan analisa dari bab-bab yang ada, maka dapat ditarik kesimpulan sebagai berikut:

1. Metode CBR mampu melakukan pengolahan data gejala penyakit infertilitas yang dipilih oleh pasien dengan menghasilkan diagnosa berupa Kemungkinan terkena penyakit infertilitas.

2. Hasil penelitian ini dapat memberikan informasi mengenai penyakit infertilitas.

\section{DAFTAR PUSTAKA}

[1] D. Aldo and D. Riliyanda, "Aplikasi Sistem Pakar Dalam Mendiagnosa Penyakit Infertilitas Pada Pria," vol. 7, no. 1, pp. 20-31, 2019.

[2] N. Ritha and M. Sutoyo, "Case Based Reasoning Untuk Mendeteksi Kerusakan Harddisk," J. Sustain., vol. 5, no. 01, pp. 15-21, 2016.

[3] D. Aldo and Ardi, "Sains dan Teknologi Informasi Sistem Pakar Diagnosa Penyakit Limfoma dengan Metode Certainty Factor," vol. 5, no. 1, 2019.

[4] T. Sutojo, E. Mulyanto, and V. Suhartono, Kecerdasan buatan. Yogyakarta: Andi, 2011.

[5] B. F. Yanto, I. Werdiningsih, and E. Purwanti, "Aplikasi Sistem Pakar Diagnosa Penyakit Pada Anak Bawah Lima Tahun Menggunakan Metode Forward Chaining," J. Inf. Syst. Eng. Bus. Intell., vol. 3, no. 1, p. 61, 2017, doi: 10.20473/ jisebi.3.1.61-67.

[6] D. R. Habibie and D. Aldo, "Sistem Pakar Untuk Identifikasi Jenis Jerawat Dengan Metode Certainity Factor," JOINTECS (Journal Inf. Technol. Comput. Sci., vol. 4, no. 3, 
p. 79, 2019, doi: 10.31328/ jointecs.v4i3.1055.

[7] W. Yulianti, "Aptitude Testing Berbasis Case-Based Reasoning Dalam Sistem Pakar Untuk Menentukan Minat Dan Bakat Siswa Sekolah Dasar," Rabit J. Teknol. dan Sist. Inf. Univrab, vol. 1, no. 2, pp. 104-118, 2016, doi: 10.36341/ rabit.v1i2.28. 